\title{
Econometric Analysis of the Impact of Fdi on Retail Trade in India
}

\author{
Dr. Debarati Mukherjee \\ (Department of Commerce \& Business Management, Ranchi University, Ranchi, India)
}

\begin{abstract}
In this paper, a time series statistical analysis has been done for predicting the growth of organized retail sales in India along with its impact on Foreign Direct Investment in retail sales. The analysis is done to identify the factors that contribute to the increase in organized retail sales and also to verify whether there exist a positive relationship between growth in retail sales and Foreign Direct Investment. Using a panel dataset of indicators from the year 1975 to 2010, a positive relationship has been found between factors like mobile cellular subscriptions (per 100 people), internet users (per 100 people), household consumption expenditure (as a percentage of GDP), consumer price index, population age group between the ages 15-64 years and urban population growth to that of retail sales. All these factors are positive and significant. Thus this study makes a significant contribution by identifying the key determinants in the predictability of organized retail sales in India, thus making a great socio- economic effect on the development of the Indian economy as a whole. The analysis also finds a positive relationship between the inflow of foreign direct investment and retail growth. This finding suggests that with the advent of international spending in India, retail will grow, and this in turn will increase the quality of the goods produced and the services rendered in India.
\end{abstract}

Key Words: Organized retail, econometric analysis, private final consumption expenditure, household final consumption expenditure, foreign direct investment, multi-co linearity, heteroskedasticity

\section{Introduction}

FDI as defined in Dictionary of Economics (Graham Bannock et.al) is "investment in a foreign country through the acquisition of a local company or the establishment there of an operation on a new (Greenfield) site. International Monetary Organization (IMF) and Organization for Economic Cooperation and Development (OECD) define FDI as a category of cross border investment made by a resident in one economy (the direct investor) with the objective of establishing a 'lasting interest' in an enterprise (the direct investment enterprise) that is resident in an economy other than that of the direct investor.

The motive of the direct investor is a strategic long term relationship with the direct investment enterprise to ensure significant degree of influence in the management of the direct investment enterprise. Besides, International Bank for Reconstruction and Development (IBRD) and United Nations Conference on Trade and Development (UNCTAD) also provide definition of Foreign Direct Investment. To put in simple words, FDI refers to capital inflows from abroad that is invested in or to enhance the production capacity of the economy.

It is preferred over other source of foreign capital because it is non-volatile, non-debt creating and results in economic development, modernization and employment generation in the economy.FDI acts as a complimentary tool to boost capital growth and investment in a country.

With the unshackling of the economy in 1991, the Indian government took certain policy measures to bring in FDI in some of the sectors. This brought about positive changes in the economy and the GDP recorded a growth of about 6\%.The highest increase in real GDP was experienced in 2007-2009 where it touched the 8.5\% -9.5\% .In the FDI Confidence Index published by A.T.Kearney in 2012 India was ranked at the second position as far as its capacity to attract foreign investors. The Government of India with the objective to attract and promote foreign direct investment in order to supplement domestic capital, technology and skills, for accelerated economic growth opened its doors for FDI in multi-brand retailing in 2012.This effort of the government could not bring in the much needed investment from foreign investors because of certain regulations. Major foreign companies like Carrefour, Tesco, Wal-Mart were against certain norms in the policy like mandatory investment in back-end infrastructure, compulsory 30 per cent local procurement norms and restrictions on cities. India's GDP showed a disappointing growth rate of 4.4 percent year Q1 FY 2013-2014.

In this scenario this paper studies a positive relationship between rise in Retail Trade in India vis-a vis FDI in Retail in India. In this paper, a time series statistical analysis has been done for predicting the growth of organized retail sales in India. The analysis is done to identify the factors that contribute to the increase in retail sales. Using a panel dataset of indicators from the year 1975 to 2010, a positive relationship has been found between factors like FDI, mobile cellular subscriptions (per 100 people), internet users (per 100 people), household consumption expenditure (as a percentage of GDP), consumer price index, population age group 
between the ages 15-64 years and urban population growth. All these factors are positive and significant. This finding suggests that with the advent of international spending in India, retail will grow, and this in turn will increase the quality of the goods produced and the services rendered in India.

Traditionally the retail industry in India was largely unorganized, comprising of drug stores, medium, and small grocery stores. Most of the organized retailing in India have started recently and is concentrated mainly in the metropolitan cities. The growth in the Indian organized retail market is mainly due to the changes in consumers' behavior. This change has come in the consumer due to increased income, changing lifestyles, and patterns of demography which are favorable. Now the consumer wants to shop at a place where he can get food, entertainment, and shopping all under one roof. This has given Indian organized retail market a major boost. One would expect a positive relationship between the FDI inflow and the retail sales.

In a recent article "Indian Retail Industry: Challenges, Opportunities and Outlook" ${ }^{1.1}$, it has been mentioned that private final consumption expenditure (PFCE) and GDP growth are indicative of the growth in the retail sector.

In the absence of time series data on retail sales in India, private final consumption expenditure (PFCE) can be used as proxy data for retail sales. So, a gain in private consumption expenditure would mean a growth in the retail sector which would in turn imply a growth in organized retail sector in India.

Moreover, private final consumption is an important component of GDP and according to Table 1.4 of the report "State of the Economy and Prospects" published in economic survey in the Indian government website ${ }^{1.2}$ consists of components such as food, beverages \& tobacco, textiles, furniture, furnishings, etc which form a major part of retail trade in India. Thus the inclusion of this variable as a proxy for growth in retail trade in India seems justified for the time series analysis done in this paper. By definition, private final consumption consists of household expenditures on durable and nondurable goods and services during a certain period of time. This is indicative of the expenditure pattern of consumers in consumption goods, so an increase in this, directly relates to the increase in retail sales.

In the paper "Growth Drivers and Challenges for Organized Retailing in India" by V. V. Gopal and A. Surya-narayana presented at the 2010 International on Business and Economics Research, the authors clearly point out that demographic changes such as increase in disposable income, increase in the proportion of young population, increase in the labor participation of women and also the increase in cellular subscriptions and internet usage has not only increased the awareness among consumers about products but has also facilitated the growth of organized retail industry in India which in turn has led to the increase in private consumption expenditure thus increasing retail sales.

In the time-series regression that follows, all these variables have been included in the model and the regression results comply with the theory that these variables indeed have a positive relationship with retail sales.

In another paper, "An Econometric analysis on organized and unorganized retail share" by Subhadip Mukherjee, the author uses a multiple regression model to find determinants that result in the growth of the organized retail sector. The authors' analysis reveals that GDP, women's participation rate, foreign investment freedom and urbanization rate of a country, positively influence the growth of the relative share of organized retail sector. This paper adds to this research by particularly looking at the growth in the retail sector using data from the years 2003-2006 and including new variables.

\section{Data and Methodology}

The model has been based mainly on secondary data. A panel dataset of indicators have been used in this study. The indicators which serve as independent variables have been obtained from the World Bank's World Development Indicator's Database ${ }^{\mathbf{1 . 3}}$. The description of the variables can be seen in the methodology section. The summary statistics of the variables are in the appendix. A set of time series regressions have been done to find out the determinants of organized retail growth in India.

In the initial set of regressions, the dependent variable that has been used is private final consumption expenditure as a proxy for retail sales. The data on private final consumption expenditure and personal disposable income (which is also a determinant of organized retail growth in India) have been obtained from Central Statistics Office. A time series regression has been done in this study for the years 1975-2010. The models for this analysis are as follows.

\section{$\underline{\text { Model A }}$}

1.1 http://www.dnb.co.in/IndianRetailIndustry/overview.asp

$1.2 \mathrm{http}: / /$ indiabudget.nic.in

$1.3 \mathrm{http}: / /$ data.worldbank.org/country/india 
Private final consumption expenditure $(\mathrm{PFCE}) \mathrm{i}=\mathrm{a}+\mathrm{b} 1(\mathrm{MCS}) \mathrm{i}+\mathrm{b} 2(\mathrm{IU}) \mathrm{i}+\mathrm{b} 3($ Inflation$) \mathrm{i}+\mathrm{b} 4(\mathrm{CPI}) \mathrm{i}+\mathrm{b} 5$

(HFGEGD)i + b6 (YoungPop)i + b7 (Urpopgr)i $+{ }^{\varepsilon_{i}}$

Where-

PFCE = household expenditures on durable and non-durable goods

and services ( in billion of rupees)

MCS = mobile cellular subscriptions (per 100 people)

IU $\quad=$ internet usage (per 100 people)

HFGEGD = Household final consumption expenditure, etc. $(\%$ of GDP)

YoungPop = Population ages 15-64 (\% of total)

Urpopgr $=$ Urban population growth

I = Years between 1975-2010

The null hypothesis that is being tested here is whether b1, b2, b4, b5, b6, b7 > 0 and if b3<0.

\section{Model B}

Private final consumption expenditure (PFCE)i $=\mathrm{a}+\mathrm{b} 1(\mathrm{MCS}) \mathrm{i}+\mathrm{b} 2(\mathrm{IU}) \mathrm{i}+\mathrm{b} 3$ (FDINETING)i $+\mathrm{b} 4$

(HFGEGD)i + b5 (YoungPop)i + b6 (Urpopgr)i $+{ }^{\varepsilon_{i}}$

Where-

PFCE = household expenditures on durable and nondurable goods and

services ( in billion of rupees)

MCS = mobile cellular subscriptions (per 100 people)

IU = internet usage (per 100 people)

FDINETING $=$ Foreign direct investment, net inflows (\% of GDP)

HFGEGD = Household final consumption expenditure, etc. ( $\%$ of GDP)

YoungPop = Population ages 15-64 (\% of total)

UrPopGr = Urban population growth

$\mathrm{i}=$ Years between 1975-2010

The null hypothesis that is being tested here is whether b1, b2, b3, b4, b5, b6 > 0

\section{Results and Interpretation}

Ordinary least squares regression analysis for the model formulated has been used using the STATA package. Two models have been used in the analysis the results for which can be seen in Table 1.2, 1.3 respectively. The difference between Model A and Model B is that the independent variable FDI net inflows (as a \% of GDP) has been used in Model B instead of CPI and Inflation that has been used in Model A. This has been done to avoid the problem of multi - co linearity. The Results from the two models show no significant multi - co linearity.

For Model A, the following null hypothesis was tested. It has tested to see whether mobile cellular subscriptions (per 100 people), internet users (per 100 people), household consumption expenditure (as a percentage of GDP), consumer price index, population age group between the ages 15-64 years and urban population growth has a positive impact on the private final consumption expenditure which is a proxy for retail sales leading to the growth of retail trade in India. The results show that all the coefficients of the above independent variables are positive and thus have a positive relationship with the growth of retail trade.

The variables mobile cellular subscriptions (per 100 people), population age group between the ages 15-64 years and urban population growth are significant at $1 \%$ level of significance. This means that these variables are strong determinants in predicting the growth of organized retail in India. This can be justified in the following way.

The increase in the urban population leads to an increase in the aspirational class. The major beneficiary is the retail industry. We see this in the results where a $1 \%$ increase in the growth of the urban population results in an increase in 2173.195 billion rupees in retail sales. This in turn shows that as the organized retail sector grows, more and more people will tend to go to malls and supermarkets thus increasing retail sales to a great extent.

The age group between 15- 64 years are the ones who buy at supermarkets and malls. A positive relationship between this age group and the rise in consumption expenditure tells us that an increase in $1 \%$ of the population of this age group will result in an increase of 2901.55 billion rupees in retail sales. Thus, increase in the middle and high income population will help the India's consumer market grow. This also points out to the fact that increased awareness has resulted in a perceptible change in behavior of the consumers and they are now on the lookout for convenience, speed, efficiency and a wide range of products, simultaneously $-\mathrm{a}$ one-stop shopping experience. The economic well being, increasing aspirations for higher standards of living 
and comforts for this age group of consumers are responsible for the increase in consumerism and thus an increase in the organized retail sector.

Technological advances such as the increase in the number of mobile subscriptions is an important driver of change in the retail industry. From the results we can infer that an increase in $1 \%$ of mobile cellular subscription will result in the increase of 205.6643 billion rupees in retail sales. Mobile marketing is an available tool through which awareness among the consumers is increased, thus leading to higher organized retail sales.

Internet usage also has a positive impact on the retail industry with the coefficient being positive (growth in $1 \%$ of internet users will result in a 640.272 billion rupees increase in retail sales) and significant at $5 \%$ level of significance. With the increase in internet usage, online retailing is coming up as an alternate channel for growth.

Software now enables retailers in planning the store layout, managing shelves and designing interiors at the supermarket and malls leading to better management and sales as consumers can now get a better vivid picture of the things on sale just overall increasing sales. CRM software applications aids retailers in developing a database of customers under different classifications thus making them aware of the consumers' needs and helping them in the development of the product based on needs. This has direct impact on retail sales as now both retailers and consumers are happy.

The variables consumer price index and household consumption expenditure have positive coefficients significant at $20 \%$ and $10 \%$ respectively. The positive coefficients signify that these variables do have a positive impact on the organized retail sector but are not so strong determinants of the growth.

Inflation has a negative relationship with private consumption expenditure and this can be justified by the fact that as inflation increases, prices of commodities will increase leading to a decrease in retail sales and subsequently resulting in a decrease in the sales of organized retail sector in India.

Consumer price index is a measure of the amount paid by typical consumers for retail goods and other items. We see a positive relationship between this variable and the dependent. The logic for this is very intuitive as an increase in the amount paid by customers will increase the retail sales.

In Model B, we see similar results as in Model A. The new variable, inflow of foreign direct investment that has been added to Model B has a positive relationship with private consumption expenditure in turn signifying a positive relationship with organized retail growth in India. The coefficient is significant at $20 \%$ level of significance.

This positive relationship can be justified by the fact that foreign direct investment inflow helps raise funds to invest in more number of retail stores (which require huge investment). So, any dearth of domestic capital that can prevent the establishment of this type of retail outlets will be fulfilled by FDI inflows.

\section{Graphical Representation}

Model A:

Dependent variable $=$ household expenditures on durable and nondurable goods and services;

Independent variables represented in the graph.

Positive relationship is shown between dependent and independent variables.

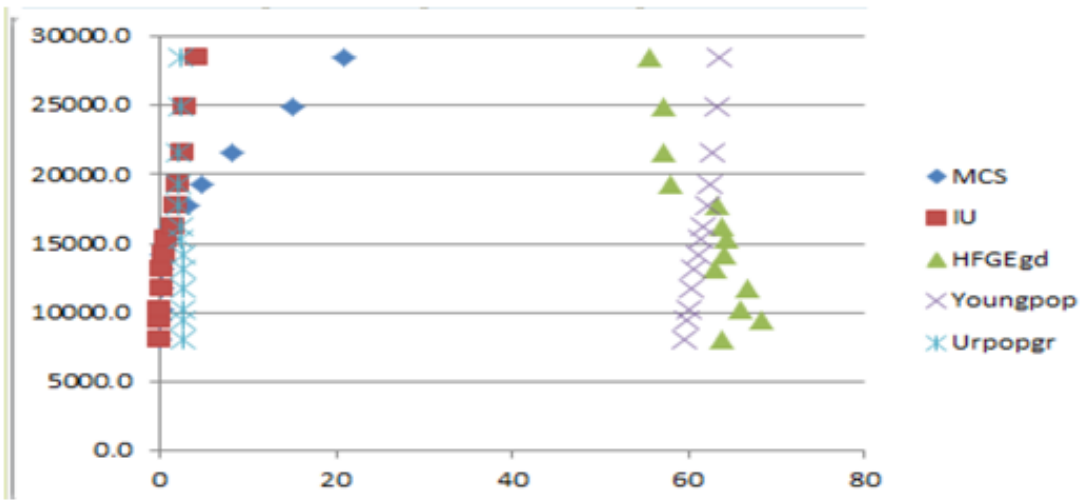

Model B:

Dependent variable=household expenditures on durable and nondurable goods and services

Positive relationship between both dependant and independent variables 


\section{Expenditure vs FDI Inflow}

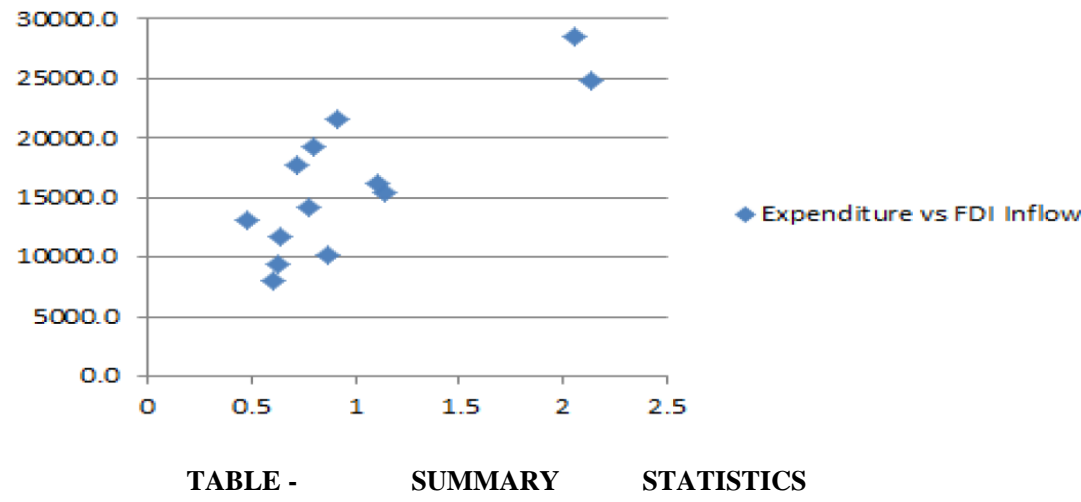

\begin{tabular}{|c|c|c|c|c|c|}
\hline VARIABLE & OBSERVATIONS & MEAN & $\begin{array}{l}\text { STANDARD } \\
\text { DEVIATION }\end{array}$ & MINIMUM & MAXIMUM \\
\hline FDINETING & 36 & 0.5988548 & 0.8401099 & -0.0301183 & 3.569616 \\
\hline INFLATION & 36 & 7.405547 & 4.085152 & -7.634381 & 13.87025 \\
\hline CPI & 36 & 56.42395 & 39.79134 & 11.63436 & 151.9106 \\
\hline MCS & 36 & 5.409871 & 13.96231 & 0 & 64.23824 \\
\hline IU & 36 & 0.9588984 & 1.85523 & 0 & 7.843803 \\
\hline HFGEGD & 36 & 65.56166 & 4.970286 & 55.58448 & 74.60824 \\
\hline GDPGR & 36 & 5.905079 & 2.937441 & -5.237586 & 9.817003 \\
\hline YOUNG POP & 36 & 59.50667 & 2.546335 & 56.35976 & 64.48966 \\
\hline URPOPGR & 36 & 2.85897 & 0.5672154 & 2.066365 & 3.96014 \\
\hline PFCE & 36 & 10473.26 & 11253.58 & 730.6 & 43383.9 \\
\hline
\end{tabular}

Where $\rightarrow>$

FDINETING $=$ Foreign Direct Investment, net inflows (\% of GDP)

MCS = mobile cellular subscriptions (per 100 people)

IU = internet usage (per 100 people)

HFGEGD = Household final consumption expenditure, etc. (\% of GDP)

YoungPop = Population ages $15-64$ (\% of total)

UrPopGr = Urban population growth

PFCE = household expenditures on durable and nondurable goods and services ( in billion of rupees)

Table 1: Regression results of Model A

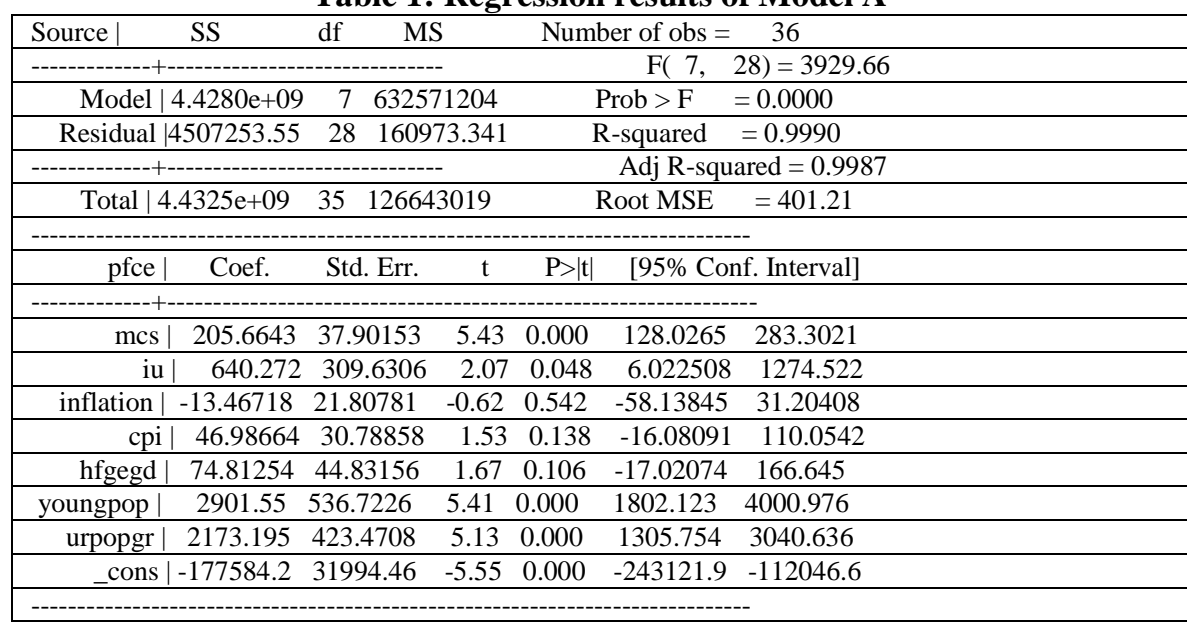


Table 2 - Regression results of Model B

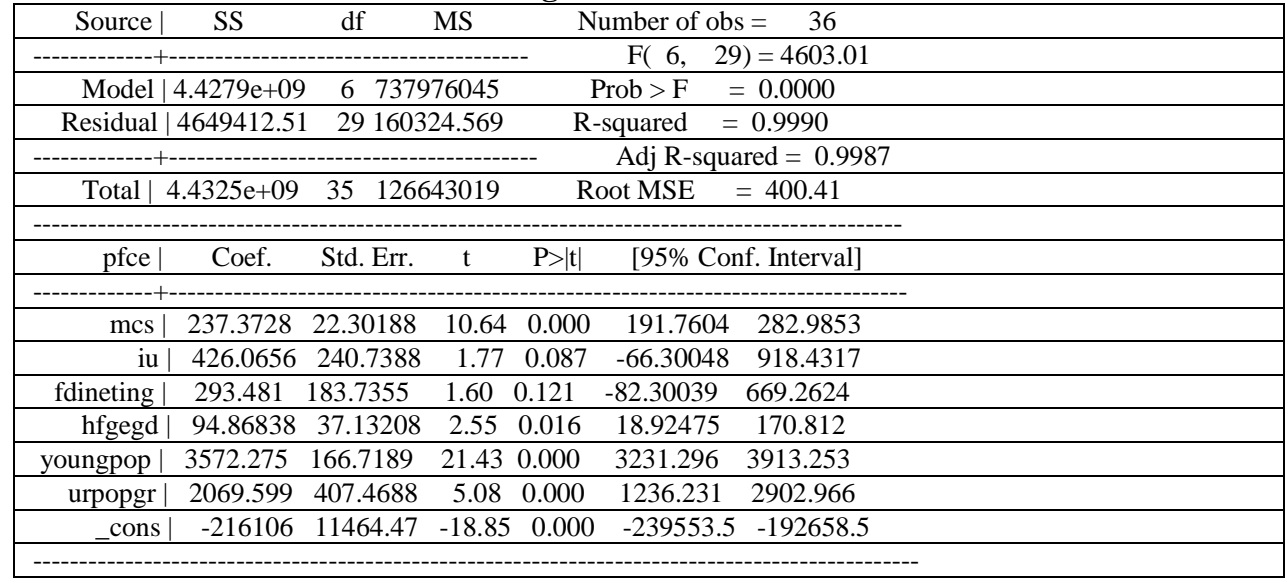

Table 3: Test of heteroskedasticity in the models

Model A

Breusch-Pagan / Cook-Weisberg test for heteroskedasticity

Ho: Constant variance

Variables: fitted values of pfce

$\operatorname{chi} 2(1)=0.54$

Prob $>$ chi $2=0.4640$

\section{Model B}

Breusch-Pagan / Cook-Weisberg test for heteroskedasticity

Ho: Constant variance

Variables: fitted values of pfce

$\operatorname{chi} 2(1)=1.52$

Prob $>$ chi $2=0.2183$

\section{Conclusion}

From the above econometric analysis on the retail sector, it can be concluded that the growth in organized retail is positively related with different socio-economic factors like mobile cellular subscriptions (per 100 people), internet users (per 100 people), household consumption expenditure (as a percentage of GDP), consumer price index, population age group between the ages 15-64 years urban population growth, gross domestic product growth and to the inflow of foreign direct investment.

For a developing economy like India all the above factors are likely to be increase in future and which will definitely increase the growth of organized retail share in India. In the long run this can have a great socialeconomic effect on the development of the Indian economy as a whole. The growth in organized retail will increase competition among retailers and the consumer will benefit from the increase in the variety of the product line available. With the advent of international spending in the form of foreign direct investment, the quality of the products will increase, raising the bar for goods and services. Allowing FDI in multi brand retail can bring about supply chain improvement, investment in technology, manpower and skill development, tourism development, development in agriculture, efficient small and medium scale industries.

The government approved British retail giant Tesco Plc's plan to invest $\$ 110$ million to buy 50 per cent stake in Tata Group's Trent Hypermarket Ltd (THL). With this, Tesco will become the first foreign player to open stores here. The nod given by the Foreign Investment Promotion Board (FIPB) is expected to open the doors for future investments by foreign retailers. ${ }^{1.4}$

The Indian government has taken various steps in the last few months to give a much needed boost to foreign direct investment.

Few of the initiatives taken by the government are like:

a) raising the limits on foreign investments in sectors that include insurance and defense;

b) a cap raised to 100 percent in telecommunication; and

c) relaxing investment norms in multi-brand retail to give more clarity and space to investors. 
Several other important bills were passed like the company bill to enhance transparency in company operations, the food security bill to ensure nutritional security and thus improve living standards for the poor, and the land acquisition bill to ensure fair compensation to farmers.

\section{References}

[1]. Ahluwalia, M. S. (2011), "FDI in multi-brand retail is good, benefits farmers", The Times of India, http://timesofindia.indiatimes.com/ business/ india-business/ FDI-in-multi-brand-retail-is-good-benefits-farmers-Montek-/ articleshow/ 7328844.cms\#ixzz1EmeD95sm”.

[2]. Balasubramanyam V.N, Sapsford David (2007): "Does India need a lot more FDI", Economic and Political Weekly, pp.1549-1555.

[3]. Basu P., Nayak N.C, Archana (2007): "Foreign Direct Investment in India Emerging Horizon", Indian Economic Review, Vol. XXXXII. No.2, pp. 255-266.

[4]. Biswas, R. (2002) "Determinants of foreign direct investment," Review of Development Economics, 6 (3), pp. $492-504$.

[5]. Chetan Bajaj, Rajnish Tuli \& Nidhi Srivastava, Retail Management, Oxford University Press

[6]. DIPP. (2012, April). Consolidated Fdi Policy. Retrieved January 2013, from http://dipp.nic.in/English/Policies/FDI Circular 01 2012.pdf

[7]. FDI:Indian Retail Bids for a Brighter Future .A C\&W Publication, January 2012

[8]. Foreign Direct Investment Statistics How Countries Measure FDI 2001 International Monetary Fund FDI Confidence Index,2012 A. T. Kearney

[9]. Handbook of Industrial Policy and Statistics (2007-08), Government of India.

[10]. http://news.bbc.co.uk/1/hi/world/3575994.stm

[11]. http://www.atkearney.com/index.php/Publications/global-retail-developmentindex.html

[12]. http://www.business-standard.com/article/companies/tesco-vodafone-receive-big-bang-fdi-clearances-113123000596 1.html.

[13]. http://www.indianrealtynews.com/retailmarket/organised-retail-losing-itspath.html\#more-2308

[14]. Impact of organised retail on unorganised retail in India, Indian Council for Research on International Economic Relations (ICRIER) Retail report, 2008, pg.no:1-20(http://dipp.nic.in / English/ Publications/ Reports/icrier_report_27052008.pdf)

[15]. Kearney A.T. (2010), “A. T. Kearney Global Management Consultants : Expanding Opportunities for Global Retailers”, 2010 The A.T. Kearney Global Retail Development Index.

[16]. Kulwinder Singh (2005): "Foreign Direct Investment in India: A Critical analysis of FDI from 1991-2005", papers.ssrn.com/sol3/papers.cfm_id_822584.

[17]. Kumar, N (1995): "Industrialisation, Liberalisation and Two Way Flows of Foreign Direct Investments: Case of India", Economic and Political Weekly, Vol.48.pp.3228-3237.

[18]. Rajan,Ramkishen S., Sunil Rongala and Ramya Ghosh (2008), „Attracting Foreign Direct Investment (FDI) to India

[19]. RBI. (2000, May 17). Foreign Exchange Management regulation. Retrieved December 2012, from http://rbi.org.in/scripts/BS_FemaNotifications.aspx?Id=164

[20]. Swapna Pradhan (2010), RetaillingManagement, Tata Mc-graw Hill 